\title{
Relationship between Cartoon Violence and Aggressive Behavior among Primary School Children
}

\author{
Anwaar Hamed Ali ${ }^{1}$, Sayeda Ahmed Abdellatif ${ }^{2}$, Mawaheb Mahmoud Zaki ${ }^{3}$ and Hend \\ Ahmed Mostafa ${ }^{4}$
}

(1) Nursing Supervisor at Neurosurgery Hospital in Shbein-Elkom, (2) Professor of Psychiatric Mental Health Nursing, Faculty of Nursing, Cairo University, (3) Assistant Professor of Psychiatric and Mental Health Nursing, Faculty of Nursing, Benha University, and (4) Lecturer of Psychiatric and Mental Health Nursing, Faculty of Nursing, Benha University

\begin{abstract}
Background: Cartoon violence causes significant changes on the behavior of children especially among primary school children such as aggressive behavior. Aim: Aim of this study was to assess the relationship between cartoon violence and aggressive behavior among primary school children. Research design: A descriptive design was utilized in this study. Setting: This study was conducted at selected primary governmental schools in Benha city at Qaliubiya Government. Sample: A multistage random sample from (400) children was taken from the previously mentioned setting by taken randomly one grade from selected school then taken all children from these grades. Tools: (I): A structured interviewing questionnaire sheet, (II): Attitude scale for children toward cartoon violence, (III): Aggression scale for children. Results: More than three quarters of the studied primary school children's had a positive attitude toward cartoon violence and more than half of them had severe level of aggression. Also, there was positive significance correlation between children's attitude toward cartoon violence and their aggressive level. Conclusion: Cartoon violence influence positively on aggressive behavior among the primary school children as There was a positive significant correlation between cartoon violence and aggressive behavior among the studied primary school children. Recommendations: Parents should put consistent limits on hours per day of cartoon watching and encourage their children to do other physical and social activity such as reading, drawing and any sports in spite of spending time on cartoons watching.
\end{abstract}

Key words: Cartoon violence, Aggressive behavior, Primary school children

\section{Introduction:}

Children are believed to be the future of the nation. The period of childhood is very critical because in this period behaviors can be easily molded. Children learn and develop skills by interacting, observing, and imitating the creations around them. Media such as cartoon films is on the forefront means influencing children's lives nowadays. Children, being easily influenced by their surrounding environment, are at greater risk mainly due to the ability of T.V and media content to affect their development, behavior and entire life, which can either build or break them ( Abu-Seada , 2019).

A cartoon watching is a big entertainment source for school age children. Many children spend their time watching television because the busy schedule of parents allows them to expend less time with their children. It delineating violence and aggressive behavior that can inspire children 
to become violent in actual life (Parivan \& Islam, 2020).

Cartoons watching delineating violence and aggressive behavior that can inspire children to become violent in actual life. Children who see that violence is very realistic, are often repetitive or unpardonable, are more likely to imitate them. Experts at American Academy of Pediatrics say that children who watch cartoons full of violence tend to be hateful, aggressive, and disobedient. The cartoon has three main effects that concern violence against children such as children are at risk of aggressive reactions and violent behavior ( Parivan \& Islam, 2020).

Psychiatric Mental Health Nurse is not able to control behaviors of children only, but she can control their response to those behaviors. Nursing role is centered in demonstrating care, active listening and therapeutic interactions. Interventions that prevent violence and aggression are supporting, decreasing risk factors, removing element of violence such as target, trigger ,weapon and state of arousal of children ( Hannan et al ., 2019 ).

\section{Significance of the study:}

In Egypt, children represent around $40 \%$ of the total Egyptian population. Basic research results suggest that many Egyptian children engage in around 3 to 4 hours of media content daily. This is around 21 hours weekly, 90 hours monthly, and 1095 hours yearly (which is almost one month and half of each year of their lives continuously (AbuSeada, 2019)

More ever, the prevalence of school violence as a result of cartoon watching in Egypt reported $35 \%$ violent traits and $11.7 \%$ violent behavior among primary school students .It was found that $51 \%$ of boys and $20 \%$ of girls in primary schools had initiated violent attacks at schools ( Galal et al ., 2019) .

\section{Aim of the study:}

Aim of this study was to assess the relationship between cartoon violence and aggressive behavior among primary school children.

\section{Research question:}

What is the relationship between cartoon violence and aggressive behavior among primary school children?

\section{Subject and Methods}

\section{Research Design:}

A descriptive design was utilized in this study.

\section{Research Setting:}

This study was conducted at selected primary governmental schools in Benha city at Qaliubiya Government.

\section{Research subject:}

\section{Sample Size:}

A multistage random sample from children was taken from the previously mentioned setting by taken randomly one grade from selected governmental primary schools then taken all children from these grades.

\section{Sample technique:}

A multistage random sample of 400 students from the above mentioned setting who will fulfill the following

\section{Inclusion criteria:}

1. Aged from 6-12 years.

2. Both sexes.

3. Willing to participate in this study.

\section{Tools of Data Collection:}

\section{Tool (I): A Structured Interviewing} Questionnaire Sheet 
It was developed by the researcher to achieve the aim of the study after reviewing related literature and it include the following parts:

Part (1): Characteristics of the studied sample:

- A: Characteristics of the studied children.

Part (2): Concerning children knowledge regarding cartoons watching

\section{Tool (II): Attitude Scale for Children toward Cartoon violence}

This scale was adapted from (Odukomaiya, 2014). This scale was used to assess the attitude of children toward cartoon violence. It consists of 16 items. The total scoring system of children attitude toward cartoon violence calculated and classified in two levels as following:

- $\quad$ For positive attitude $\geq 60 \%$ as range from (20-32) degree.

- $\quad$ For negative attitude $<60 \%$ as range from $(0$ - 19) degree.

\section{Tool (III): Aggression Scale for Children}

This scale was developed by (Dodge $\boldsymbol{\&}$ Coie, 1987). This scale was used to assess the aggression of children. It contains 25 items. The total scoring system of aggression scale will be calculated and classified in three levels as following:

- For Sever aggression $>70 \%$ as range from ( $>35$ degree ).

- For Moderate aggression 50- $70 \%$ as range from (25- 35 degree).

- For Mild aggression < 50\% as range from (0- 24 degree).

\section{Validity and reliability:}

The tools were tested and evaluated for their face and content validity, and reliability.
Face and content validity were tested by five experts in psychiatric and mental health nursing field.

\section{Reliability of tools:}

Reliability was applied by the researcher for testing the internal consistency of the tools. Answers from repeated testing were compared (Test-re-Test reliability) by using Alpha Cronbach reliability. The tools were strongly reliable at (0.92) for Attitude Scale for Children toward Cartoon Violence and ( 0.94) for Aggression Scale for Children

\section{Pilot study:}

A pilot study was conducted to test the clarity, reliability, and applicability of tools. To achieve that, the study was tested on $10 \%$ of the total sample as (40) students in the primary school. This sample was excluded from the actual study sample.

\section{Field work:}

Official permission from Faculty of Nursing/Benha University to the Administrators of the governmental primary school at Benha city about the aim of the study was taken to conduct the study. The researcher introduced herself to the director of every governmental school chosen. Oral consent was obtained from every child who fulfills the inclusion criteria. The actual field work was carried out over about 3 months from the middle of October 2020 to the end of December 2020. The researcher visited the selected governmental primary schools at Benha city from 9 am to $1 \mathrm{pm}$, every 3days per week to collect data from children. An individual interviewing was conducted for every child to collect the necessary data using the tools for data collection attitude toward cartoon violence and aggression scale. 
The average time needed for this sheet was around (25-30) minutes. The researcher visited this selected governmental primary schools 3 days per weeks and be stressed in data collection due to (COVID- 19 disease).

\section{Ethical considerations:}

All children were informed that participation in the study was voluntary; no name was included in the questionnaire sheet. Confidentiality was assured and all children Results:

Table (1): Shows that $29.3 \%$ of the studied primary school children their age ranged between 10-<12 years, the Mean SD of age was $9.62 \pm 2.90$ years. As regard to gender, $51.5 \%$ of the primary school children are males. Also, $20 \%$ of the primary school children are at first grade. Concerning residence, $84 \%$ of them are living in urban areas.

Table (2): Reveals $51 \%$ of them are watching television from $4-<6$ hours. Also, all of the studied primary school children watching cartoon and less than half of them are watching cartoon from 3-<4 hours, ( $100 \%, 46.3 \%$ respectively). Likewise, more than half ( $57.5 \%$ ) of the primary school children watching action cartoon.

Table (2) continue Shows percentage distribution of the studied primary school children according to their knowledge about cartoons watching. It illustrates that near to half $(45 \%)$ of the studied primary school children watching cartoons at television.The majority $(82.5 \%)$ of them were watching cartoon with their brother $\&$ sister. In addition , nearly half of studied primary school children can imitate cartoon characters and were informed that the content of the tool was used for research purpose only and they had the right to refuse to participate in the study or withdrawal at any time.

\section{Statistical analysis:}

The statistical analysis of data was done by using the computer software of Microsoft Excel Program and Statistical Package for Social Science (SPSS) version (20)

mentioned that cartoon watching leads to aggressive behavior $(47.7 \% \quad, 47.5 \%$ respectively ).

Figure (1): Shows Percentage distribution of the studied primary school children according to their total attitude toward cartoon violence. It reveals that more than three quarters ( $76 \%$ ) of the primary school children have positive attitude toward cartoon violence. While, $24 \%$ of them have negative attitude.

Figure (2): Reveals percentage distribution of the studied primary school children according to their total aggression scale. It shows that more than half ( $51 \%$ ) of the studied primary school children's have severe level of aggression. Also, less than one third $(31.5 \%)$ of them have moderate level. While, the minority $(17.5 \%)$ of them have mild level of aggression.

Table (3): Illustrates correlation between total attitude toward cartoon violence scale and total aggression scale among the studied primary school children. It reports that there is a highly significant positive correlation between children's attitude toward cartoon violence and their aggressive levels at $(\mathrm{P}-\text { value }<0.01)^{* *}$. 
Table (1): Percentage distribution of the studied primary school children according to their socio-demographic characteristics $(n=400)$.

\begin{tabular}{|c|c|c|}
\hline \multirow[t]{2}{*}{ Children Socio-demographic characteristics } & \multicolumn{2}{|c|}{$\begin{array}{c}\text { Studied } \\
\text { sample }(n=400)\end{array}$} \\
\hline & $\mathbf{N}$ & $\%$ \\
\hline \multicolumn{3}{|l|}{ Age (years) } \\
\hline $6-<8$ years & 106 & 26.5 \\
\hline $8-<10$ years & 100 & 25 \\
\hline $10-<12$ years & 117 & 29.3 \\
\hline 12 years & 77 & 19.2 \\
\hline Mean SD & \multicolumn{2}{|c|}{$9.62 \pm 2.90$} \\
\hline \multicolumn{3}{|l|}{ Gender } \\
\hline Male & 206 & 51.5 \\
\hline Female & 194 & 48.5 \\
\hline \multicolumn{3}{|l|}{ Academic grade : (primary) } \\
\hline First grade & 80 & 20 \\
\hline Second grade & 76 & 19 \\
\hline Third grade & 64 & 16 \\
\hline Fourth grade & 68 & 17 \\
\hline Fifth grade & 52 & 13 \\
\hline Six grade & 60 & 15 \\
\hline \multicolumn{3}{|l|}{ Residence } \\
\hline Rural & 64 & 16 \\
\hline Urban & 336 & 84 \\
\hline
\end{tabular}


Table (2): Percentage distribution of the studied primary school children according to their knowledge about cartoons watching $(n=400)$.

\begin{tabular}{|c|c|c|}
\hline \multirow{2}{*}{ Children Knowledge about cartoons watching } & \multicolumn{2}{|c|}{$\begin{array}{l}\text { Studied sample } \\
(n=400)\end{array}$} \\
\hline & $\mathbf{N}$ & $\%$ \\
\hline \multicolumn{3}{|l|}{ Having television at houses } \\
\hline Yes & 400 & 100 \\
\hline No & 0 & 0 \\
\hline \multicolumn{3}{|l|}{ Watching television } \\
\hline Yes & 400 & 100 \\
\hline No & 0 & 0 \\
\hline \multicolumn{3}{|l|}{ If yes, How many hours of watching television? } \\
\hline $1-<2$ hours & 22 & 5.5 \\
\hline $2-<4$ hours & 94 & 23.5 \\
\hline $4-<6$ hours & 204 & 51 \\
\hline$\geq 6$ hours & 80 & 20 \\
\hline Mean SD & & \\
\hline \multicolumn{3}{|l|}{ Watching Cartoon } \\
\hline Yes & 400 & 100 \\
\hline No & 0 & 0 \\
\hline \multicolumn{3}{|l|}{ If yes, Numbers of hours watching cartoon in a day? } \\
\hline $1-<2$ hours & 68 & 17 \\
\hline $2-<3$ hours & 92 & 23 \\
\hline $3-<4$ hours & 185 & 46.3 \\
\hline $4-<5$ hours & 40 & 10 \\
\hline$\geq 5$ hours & 15 & 3.7 \\
\hline $\begin{array}{ll}\text { Mean SD } & 3.98 \pm 1.95 \\
\end{array}$ & & \\
\hline \multicolumn{3}{|l|}{ * Types of Cartoon } \\
\hline Action & 230 & 57.5 \\
\hline Comedy & 112 & 28 \\
\hline Science fiction & 50 & 12.5 \\
\hline Horror & 8 & 2 \\
\hline \multicolumn{3}{|l|}{ Watching programs or series rather than cartoon } \\
\hline Yes & 290 & 72.5 \\
\hline No & 110 & 27.5 \\
\hline \multicolumn{3}{|l|}{ * If yes, mention $(n=290)$} \\
\hline Films & 190 & 65.5 \\
\hline Songs & 72 & 24.8 \\
\hline Series & 28 & 9.7 \\
\hline Wresting & 100 & 8.6 \\
\hline Programs & 46 & 15.9 \\
\hline
\end{tabular}

(*) select more than one answer. 
Table (2) continue: Percentage distribution of the studied primary school children according to their knowledge about cartoons watching $(n=400)$.

\begin{tabular}{|c|c|c|}
\hline \multirow{2}{*}{$\begin{array}{c}\text { Children Knowledge about cartoons watching } \\
\text { (continue ) }\end{array}$} & \multicolumn{2}{|c|}{$\begin{array}{c}\text { Studied } \\
\text { sample }(n=400)\end{array}$} \\
\hline & $\mathbf{N}$ & $\%$ \\
\hline \multicolumn{3}{|l|}{ Devices of Cartoons Watching } \\
\hline Lab top & 15 & 3.8 \\
\hline Television & 180 & 45 \\
\hline Tablet & 22 & 5.5 \\
\hline Mobile & 130 & 32.5 \\
\hline computer & 53 & 13.2 \\
\hline \multicolumn{3}{|l|}{ Cartoons Watching only } \\
\hline Yes & 160 & 40 \\
\hline No & 240 & 60 \\
\hline \multicolumn{3}{|l|}{ If No, Who are you watching cartoons with? $(n=240)$} \\
\hline brother \& sister & 198 & 82.5 \\
\hline Mother & 16 & 6.7 \\
\hline Father & 4 & 1.6 \\
\hline other & 22 & 9.2 \\
\hline \multicolumn{3}{|l|}{ Advantages of cartoon watching } \\
\hline Acquire new skills & 23 & 5.8 \\
\hline Learn how to solve problems & 16 & 4 \\
\hline Entertainment & 34 & 8.5 \\
\hline An imitation of cartoon characters & 191 & 47.7 \\
\hline I don't know & 136 & 34 \\
\hline \multicolumn{3}{|l|}{ Disadvantages of cartoon watching } \\
\hline Social isolation & 70 & 17.5 \\
\hline Wasting time & 95 & 23.8 \\
\hline Acquire aggressive behavior & 190 & $\mathbf{4 7 . 5}$ \\
\hline Acquire wrong information & 40 & 10 \\
\hline I don't know & 5 & 1.2 \\
\hline
\end{tabular}

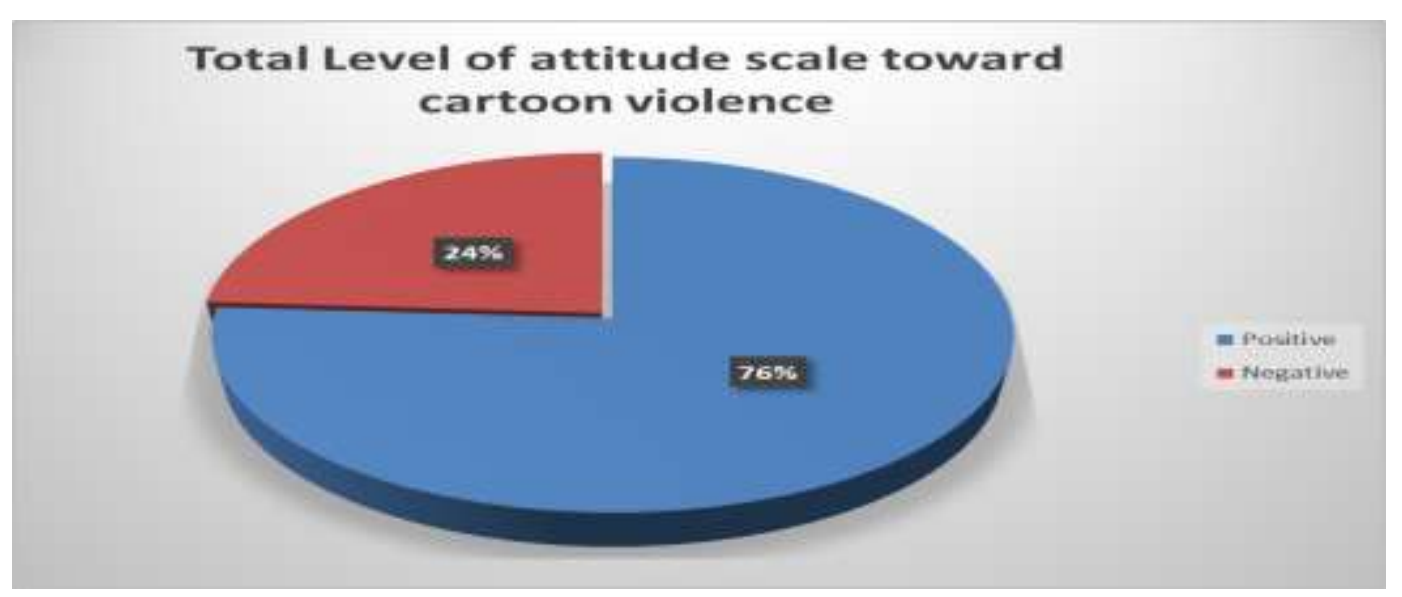

Figure (1): Percentage distribution of the studied primary school children according to their total attitude toward cartoon violence 


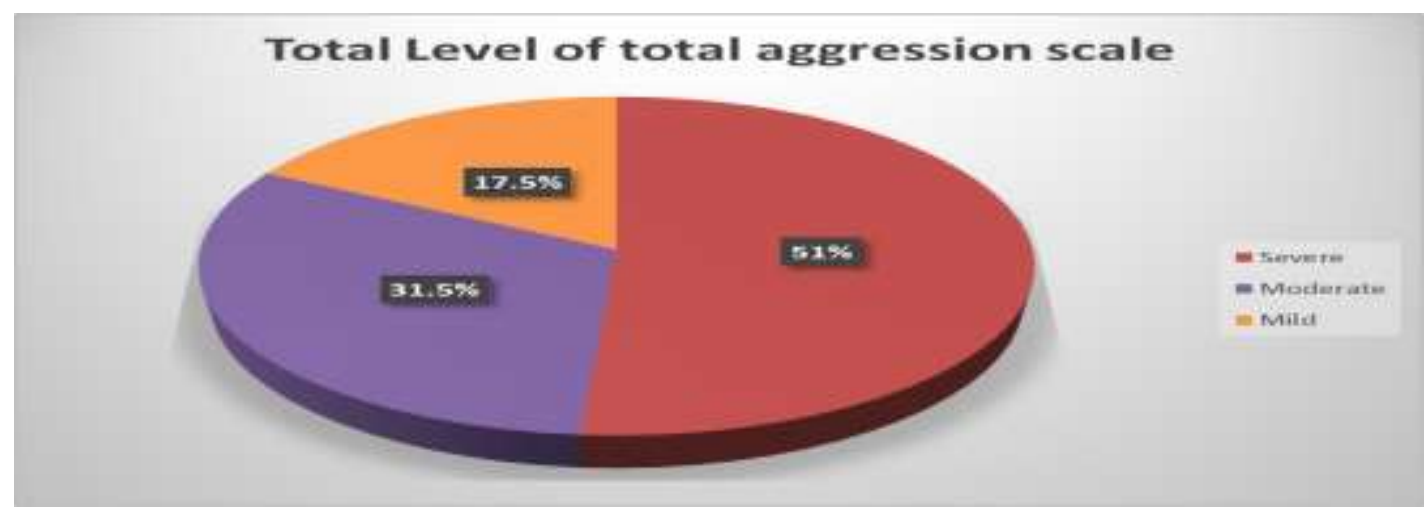

Figure (2): Percentage distribution of the studied primary school children according to their total aggression scale

Table (3): Correlation between total attitude toward cartoon violence scale and total aggression scale among the studied primary school children $(n=400)$.

\begin{tabular}{||l|c|c|}
\hline \multirow{2}{*}{ Items } & \multicolumn{2}{c|}{ Total attitude level toward cartoon violence } \\
\hline \multirow{2}{*}{ Total aggression level } & \multicolumn{1}{|c|}{$\mathbf{r}$} & p- value \\
\cline { 2 - 3 } & 652 & $0.000^{* *<}$ \\
\hline
\end{tabular}

\section{Discussion:}

Cartoons are the reflection of an imaginary life that can affect the children in many ways. There are several TV Channels which broadcast Cartoons non-stop. Over the years, children have become more interested in cartoons because these cartoons are funny, interesting and full of colors (Sharma, \& Suri, 2020). Therefore, this study aimed to assess the relationship between cartoon violence and aggressive behavior among primary school children.

Regarding to the demographic characteristics of the studied primary school children, the finding of the current study revealed that, more than one-quarter of the primary school children their age ranged between $10-<12$ years, the Mean SD of age was $9.62 \pm 2.90$ years, more than half of them were male. These results were similar with
Helseth et al., (2018) who conducted revealed that the Mean SD of students' age was $\mathrm{M}=9.04, \mathrm{SD}=1.98$ years. Also, more than half of students were male. But these results disagreement with Soydan et al., (2016) who indicated that the mean age of his studied sample was $4.97 \pm 1.52$ year with highest range between 4.5-5.5 year. Also, more than half of them were female.

In relation to residence, the results of the current study indicated that the majority of them residing in urban areas. These results might be due to this study conducted at selected primary governmental schools in Benha city at Qaliubiya Government. These results were in the same line with the study performed by Zughayer \& Shaabeth (2020) who stated that more than three fifth of the studied sample were residing in urban areas. 
The current study findings revealed that less than half of them were watching cartoon from 3-<4 hours, more than half of them prefer watching action cartoon. These results go in agreement with Rai et al., (2017) who stated that more than two-thirds of samples pass more than 4 hours watching cartoon. Though it was considered that action cartoon was a favored way of entertainment. In the same line , Mahmood et al., (2020) revealed that television was the most popular medium in which the children were exposed and cartoon films were the most thing watched by the majority of his studied sample .

The results of the present study indicated that less than half of the studied primary school children imitation of cartoon characters. Moreover, less than half of them mentioned that watching cartoons leaded to aggressive behavior. These results were consistent with Zhang et al., (2019) who revealed that watching violent cartoons triggerd aggression than watching nonviolent cartoons among half of his studied sample and this supported our research hypothesis that children who watch a violent cartoon would more frequently display aggressive behaviors than those who watch a nonviolent cartoon.

The findings of the current study revealed that about three quarters of the studied primary school children's had positive attitude toward cartoon violence. While, about one quarter of them had negative attitude. These results were approved with $\mathbf{L i}$ et al., (2020) who stated that more than threequarters of the studied children had positive attitude toward cartoon violence. In the same line, Lillard et al., (2015) revealed that the majority of the studied children had positive attitude toward cartoon violence as they imitate what they watch.
The findings of the current study revealed that more than half of the studied primary school children's had severe level of aggression. Also, less than one third of them have moderate level. These results might be due to media has played as significant role in development of children as the children of today are surrounded by technology and entertainment that is full of violence. Cartoon films are very influential and if too much violence is available for children to watch, play, or listen to, this can lead to their attitudes to a negative direction. These results were consistent with Gentile et al., (2017) who found that more than two-thirds of the children had severe level of aggression. In the same line, Su (2018) revealed that the majority of studied sample had high level of aggressive as a result of watching cartoon films.

According to the correlation between children's total attitude level scale toward cartoon violence and total level aggression scale, the present study revealed that there was highly significant positive correlation between children's attitude toward cartoon violence and their aggressive levels. This could be explained as positive attitude towards cartoon violence were higher among children with aggressive behavior. These results supported with Gentile et al., (2017) \& Zhang et al., (2019) who emphasized that there was a highly significant positive correlation between children's attitude toward cartoon violence and their aggressive levels.

\section{Conclusion}

There was a great relationship between cartoon violence and aggressive behavior among primary school children as more than three quarters of the studied primary school children's had a positive attitude toward cartoon violence. While, the minority of them 
had negative attitude. More than half of the primary school children's had severe level of aggression and less than one third of them had moderate level. While the minority of them had mild level of aggression. Furthermore , There was a highly significant positive correlation between children's attitude toward cartoon violence and their aggressive levels .

\section{Recommendations}

- Children should watch television under supervision of parents as ensuring of the content of cartoons free of violence and limiting screen time of cartoon watching especially TV and mobiles .

- Encourage children to do other physical and social activity such as karate, drawing and any sports in spite of spending time on screens.

- Professionals should put effective guidelines and rules how children deal with different media devices and contents of this such as cartoon films under supervision of their parents

Further researches: Research about rules or programs that manage and control watching cartoon and its effects on children's behavior.

\section{Acknowledgments:}

- The author is so grateful to all children who agreed and participated in this study for their kind and cooperation.

- The author is also so grateful to the directors of Benha selected governmental primary school for their permission to carry out this study.

\section{References:}

Abu-Seada, N. (2019). Egyptian media policies to protect minors from harmful content and promote positive media use. Retrieved from
URI: http://dar.aucegypt.edu/handle/10526/5 $\underline{773}$, Accessed on 1/11/2020 .

Dodge, K., \& Coie, J. (1987): Social information processing factors in reactive and proactive aggression in children's peer groups. Journal of personality and social psychology, 53 (6):1146 -1158.

Galal, Y. S., Emadeldin, M., \& Mwafy, M. A. (2019). Prevalence and correlates of bullying and victimization among school students in rural Egypt. Journal of the Egyptian Public Health Association, 94(1): 18.

Gentile, D., Bender, P., Reimer, R., Nathanson,A.I.,Wash,D.A.,\&Eisenmann.J .C ., (2017). Violent video game effects on salivary cortisol, arousal, and aggressive thoughts in children. Computers in Human Behavior, 70: 39-43.

Hannan, J., Sanchez, G., Musser, E. D., Ward-Peterson, M., Azutillo, E., Goldin, D., \& Foster, A. (2019) . Role of empathy in the perception of medical errors in patient encounters , A preliminary study . BMC Research Notes, 12(1) : 1-5.

Helseth, S., Waschbusch, D., King, S., \& Willoughby, M. (2015). Aggression in children with conduct problems and callousunemotional traits: Social information processing and response to peer provocation. Journal of abnormal child psychology, 43(8): 1503-1514.

Li, M., Chen, Y., Wang, J., \& Liu, T. (2020). Children's attention toward cartoon executed photos. Annals of Tourism Research, 80: 102799.

Lillard, A., Li, H., \& Boguszewski, K. (2015). Television and children's executive function. Advances in child development and behavior, 48: 219-248. 
Mahmood, T., Iftikhar, U., \& Bhatti, M. A. (2020). Impact of Violent Cartoons on the Behaviour of Children: A Case Study of South Punjab. Journal of Business and Social Review in Emerging Economies, 6(2): 689-702 .

Odukomaiya, E. (2014). Cartoons influence towards violence and aggression in school age children in Nigeria (Doctoral dissertation, Easter Mediterranean University. (EMU) - Dogu Akdeniz Universitesi (DAU).

Parivan ,F ., \& Islam, s., (2020). The impact of cartoon programs on children physical health, intelligance, behavior and activities , European Journal of Physiotherapy and Rehabilitation Studies ,1 (1) : 32 .

Rai, S., Waskel, B., Sakalle, S., Dixit, S., \& Mahore, R. (2017). Effects of cartoon programs on behavioural, habitual and communicative changes in children. International Journal of Community Medicine and Public Health, 3(6):1375-1378.

Sharma, A., \& Suri, C. S. (2020). Effects of cartoon programs on language and behaviour of children . PalArch's Journal of Archaeology of Egypt/Egyptology, 17(6):5853-5875.

Soydan, S., Alakoç pirpir, D., \& Azak, H. (2017). Aggressive behaviours of 48-to 66month-old children: predictive power of teacher-student relationship, cartoon preferences and mother's attitude. Early child development and care, 187(8):12441258 .

Su, S., (2018). Why children have aggressive behaviors. In 2018 4th International Conference on Economics, Social Science, Arts, Education and
Management Engineering (ESSAEME 2018), Atlantis Press : 202-207.

Zhang, Q., Cao, Y., Gao, J., Yang, X., Rost, D. H., Cheng, G., ... \& Espelage, D. L. (2019). Effects of cartoon violence on aggressive thoughts and aggressive behaviors. Aggressive behavior, 45(5): 489497.

Zughayer, M., \& Shaabeth, A., (2020). The Characteristics of Bully School Students' Paintings. PalArch's Journal of Archaeology of Egypt/Egyptology, 17(7): 3701-3712 . 


\section{العلاقة بين العنف فى الأفلام الكرتونية والسلوك العدوانى بين أطفال المدارس الإبتدائية}

أنوار حامد على - سيدة أحمد عبد اللطيف ـ مواهب محمود زكى ـ هند أحمد مصطفى

تعتبر الأفلام الكرتونية مسلية ومضحكة وتثير إنتباه الأطفال نحو روح المغامرة فى عالمهم الملىء بأفلام الكرنون ـ فحينما يشاهد هؤ لاء الأطفال طائر ا يحلق فى السماء فهم يريدون أن يقلدوه ويطيروا مثله. ولكن بعض وله أفلام الكرتون تشجع على العنف والغضب و السلوك العدوانى ومما لا شك فيه فهذا يعود بالضرر على هؤلاء الأطفال من حيث سلوكهم ولغتهم وتعاملهم مع أشقائهم و إستخدامهم للكلمات البذيئة وهذا غير مقبول فى مثل هذه السن المبكرة ـ لذا هدفت هذه الدراسة إلى تقييم العلاقة بين العنف فى الأفلام الكرتونية والسلوك العدوانى العى بين أطفال المدارس الإبتدائية ، وقد أجريت هذه الدراسة على ( . ع) طالب فى المدارس الإبتدائية الحكومية المختارة فى مدينة بنها محافظة القليوبية ، حيث كثفت النتائج إلى وجود علاقة إيجابية ذات دلالة إحصائية

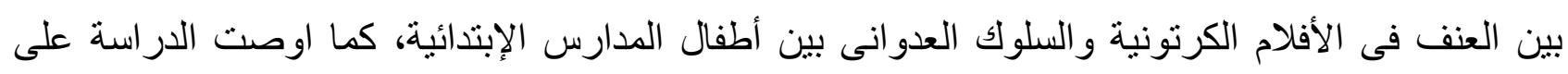
المختصين و أيضا المدرسين وضع مبادئ توجيهية وبر امج توعية حول كيفية تعامل الأطفال مع مختلف وسائل الإعلام ومحتو اها مثل أفلام الكرتون وذلك تحت إثر اف و الديهم. 